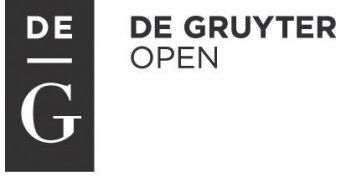

Przedsiębiorczość i Zarządzanie Entrepreneurship and Management University od Social Sciences Publishing House ISSN 1733-2486

Volume XVI, Issue 2, pp. 61-76 DOI 10.1515/eam-2015-0017

Krystyna Kietlińska

University of Social Sciences

\title{
The Forms of Social Engagement of Polish Firms
}

\begin{abstract}
The development of the idea of Corporate Social Responsibility (CSR) depends mainly on the changes in international market and growing competition between countries and enterprises. These factors influence on the behavior of enterprises. This means that the goal of business action is not only profit-making but also fulfilling social needs. The goal of this paper is to present and assess social in Poland. Starting with the concept and scope of CSR, the article presents benefits from responsible business activity and implementation of this idea in Poland.

The research carried out in 2012 shows that the main implementers of CSR are large firms with foreign capital. They know the idea of CSR from the experience of Western firms. The main objective is their image and to build better relations with their environment. On this background the article shows the ranking of companies participating in "Leader of Philanthropy" competition. It allowed to choose four firms as an example of good practices in social engagement. Social activity of chosen firms was addressed to:

- employees,

- children,

- local community,

- the sick, the disabled and the poor,

- animals.

The contacted research proves that social engagement of Polish firms is at the early stage of development. The number of firms increase, but there are mainly large companies. The main reason that the small business share in social engagement results from the limited amount of financial resources at their disposal.
\end{abstract}

Key words: social engagement, Polish firms, beneficiaries. 


\section{Introduction}

The globalization processes, changes in international markets as well as growing competition caused that since the beginning of the XXI century an increasing interest of business in social issues has been observed. This means that the goal of business actions is not only profit-making, but also the implementation of certain social objectives. This trend is called Corporate Social Responsibility (CSR) and means including in the strategies of firms the interests of various social groups, such as: employees, local community, NGOs, local government, etc. The aim of this paper is to present and assess social activities of selected firms located in Poland. The basis for the selection of socially engaged firms were the results of the "Leader of Philanthropy" contest that took place in 2013 .

\section{The concept and scope of Corporate Social Responsibility}

At the beginning of the XXI century the idea of Corporate Social Responsibility (CSR) was recognized around the world and responsible business became a global phenomenon. The business sector, which objective, by definition, is profit, takes actions on behalf of its stakeholders and the community, treating these not as a cost, but as an investment that leads to the achievement of the main objective.

The main idea of CSR was formulated at the European Summit in Lisbon in 2000. The European Council presented a 10-year socio-economic program for the Union, called the Lisbon Strategy [www.odpowiedzialny biznes.pl]. The goal of the strategy and the associated actions, called the Lisbon process, is to make the European Union the most competitive and dynamic knowledgebased economy in the world, capable of sustainable growth with more jobs and social cohesion.

In the next year (2001), in order to induce public debate on corporate responsibility, the European Commission presented a document called the Green Paper on Corporate Social Responsibility. The consultation process proceeded with participation of such EU institutions as the Commission's directoratesgeneral for employment, social affairs, enterprise and industry, information society, trade, and the environment. The debate was also made by representatives of the business sector, trade unions, media, NGOs and academic institutions [www.odpowiedzialny biznes.pl]. A year later, the Commission presented a strategy for the implementation of responsible business practices in the EU.

The appropriate institutions were set up, national parliaments started legislative processes, and the research programs were launched. The consultation 
on the Green Paper resulted in development of a new document - the White Paper: Communication on CSR. It was addressed to European institutions, Member States, social partners, business and consumer organizations.

In Poland, the concept of corporate social responsibility is developed by the oldest and the largest non-governmental organization - Corporate Responsibility Forum (Forum Odpowiedzialności Biznesu). It is a "think and do tank" organization which promotes doing business in a responsible manner, which means taking into account the impact of the firm on the society and the environment. The mission of the Corporate Responsibility Forum is promoting the idea of responsible business as a standard in Poland in order to increase the competitiveness of enterprises, social satisfaction and to improve the environment.

Based on the presented CSR concepts it is difficult to formulate a definition of this phenomenon. According to the European Commission's proposal CSR is based on the idea according to which the firms decide to help create a better society and a cleaner environment. In other words, it is a style of business management integrating social, environmental, ethical and human rights issues with business activities and the strategy, in collaboration with the stakeholders [Promoting a European Framework for Corporate Social Responsibility].

Polish authors define corporate responsibility in a similar way: "CSR is the way of firm management assuming that business decisions take into account the interest of the shareholders (owners, investors) as well as the needs of stakeholders - customers, employees, suppliers, local communities, and the environment" [Stafiej- Bartosik, Łukasiak 2008].

\section{CSR implementation measures (instruments)}

The following are the measures taken by economic entities in the process of implementation of the concept of corporate social responsibility:

- socially engaged marketing - an activity that takes into account both marketing objectives and social needs,

- socially responsible investments - funds which are invested in accordance with ethical principles,

- initiatives for the benefit of the local community, including:

- collaboration with local authorities,

- long-term investments for the benefit of the local community,

- charity projects,

- ethics programs - preventing, detecting, disclosing and correcting unethical behavior, 
- eco labeling and social marking - administering information on socially responsible activities such as care for the environment, human rights, etc. to the labels and packaging,

- corporate governance - concerns i.a. protection of minority shareholders' rights, respect for the rights of stakeholders, transparency of information,

- reports used to communicate with the environment through the presentation of the plans and achievements of the firm in the economic, environmental and social area [Łukasiewicz-Kamińska 2011, p. 84].

\section{Firms' benefits from responsible business activities}

Considering the Corporate Social Responsibility in the longer perspective, a range of benefits can be formulated that he realization of this idea can bring. The most important are:

- Increased interest of investors. Lenders are more interested in cooperation with responsible firms that are geared not only to achieve good financial results, but also to build a positive image and good relations with its environment. For many investors the financial credibility of the firm is dependent on its social credibility.

- Increase of competitiveness. The introduction of the principles of responsible business is one of the strengths, enabling firms to gain a competitive advantage. Transparent CSR policy can be one of the ways of building the firm's position in global markets, where expectations for meeting standards of responsible business are highly valued.

- Improved relations with the community and local authorities. The participation of the firm in the life of the local community, making long-term and significant social investments facilitate its efficient and harmonious functioning.

- Increased loyalty of consumers and stakeholders. Increased social awareness makes trust in the firm and its image an important factor in consumers' choices. More and more people pay attention to the compatibility of the product or service with the requirements of ecology, the principles of social responsibility in the manufacturing process and the overall reputation of the firm.

- Shaping a positive image of the firm among employees. Corporate Social Responsibility may pay the role of a non-financial motivator for employees. Employees value more the functioning of the company if they see that part of its activity is devoted to solving social problems, also important for them. 
- Attracting and retaining the best employees. When the image of the firm improves and trust among employees increases, the attractiveness of the firm in the labor market increases as well, which makes it possible to attract new and keep the best employees [Gainer 2011, pp. 190-198].

\section{Corporate Social Responsibility in Poland}

\section{The reasons for interest in the concept of CSR}

The concept of Corporate Social Responsibility in Poland has been noticed and gradually implemented as a result of the development of this idea in the highly developed European countries. The main reason for the interest of Polish firms in engagement in social issues was the desire to improve their image. The research conducted in Poland suggests that this image is perceived rather critically. Respondents emphasize the negative personality traits of entrepreneurs (superiority, flaunting their wealth, regarding oneself to be someone better) and reprehensible moral attitudes (dishonesty, failure to comply with the law) [Roguska 2004]. This negative perception of Polish business gives hope that firms will try to change this image through prosocial activities.

\section{Implementation of the idea of CSR}

The possibility of implementation of the idea of Corporate Social Responsibility in Poland depends primarily on the size of the firm and the source of capital. From this point of view, firms can be divided into two groups:

- large firms, mainly with foreign capital,

- SMEs dependent in their activities on domestic capital.

The main implementers of CSR are large companies with foreign capital. They have the necessary knowledge about CSR based on Western models of prosocial activities. The main objective of enterprises operating in this area in Poland is to improve the firm's image and to build better relations with its environment.

Difficulties in the implementation of the so formulated objectives of social activities are caused by many reasons. The most important include:

- Deficiencies in the social activity management system. In many firms there is no cost-benefit analysis and they do not assess the impact of their social activities on the prestige and profits. In most cases, the main measure of social activity is the amount of money spent. 
- Low social awareness of consumers (customers). Potential beneficiaries often accept passive social engagement of firms, or lack thereof. They do not react to unethical attitude of firms and to the lack of compliance with accepted standards of products and services offered [Kuraszko 2008, p.14].

- The research carried out in 2008 showed that $90 \%$ of managers of the largest Polish firms act in accordance with ethical principles in relations with the employees [Rok, Stolorz, Stanny 2009].

The situation in small and medium enterprises is much worse [Kuraszko 2008 , p. 13]. Their prosocial activities are limited to the sponsorship of local initiatives, thus improving relationships with local authorities and the local community. The main causes of low interest of SMEs for social issues are, i.a. insufficient knowledge on the idea of CSR and the lack of financial resources.

The second mentioned reason is connected with the necessity of the struggle to stay in the market, which is directly related to maintaining the firm's liquidity [Spoteczna odpowiedzialność biznesu...2007].

Despite these limitations, some small firms are starting to gain experience in this area. However, many SMEs still do not see the impact of their social engagement on the improvement of their financial performance.

\section{The range and scope of social activities of Polish firms}

\section{The research method}

The information about the engagement of Polish firms in social activities is a result of research. The research in this area in our country is carried out randomly, and each covers a slightly different problem range. One of them is the "Leaders of Philanthropy" contest. Although every company registered in Poland can take part in the contest, due to the very precise and consequently obeyed selection criteria the number of participants is rather small.

The prerequisite for participation in the contest is filling out the survey, in which it is necessary to show the total amount of financial donations provided for social purposes in the previous year as well as a gross profit of the firm. The survey must be accompanied by a full list of donations with detailed information on the beneficiaries and the value of resources donated to them. In addition, during the verification of data firms are required to submit the profit and loss account together with the auditor's opinion. 
Ranking of companies is developed in two categories:

- $\quad$ firms which provided the most funds for social purposes in the previous year,

- firms which provided the largest percentage of their pre-tax income for social purposes [www.forumdarczyncow.pl].

This contest has been organized for 7 years - since 2007 .

\section{Ranking of companies participating in "Leaders of Philanthropy" competition}

The total value of donations provided by firms during 7 years increased steadily. An exception was the year 2010, when the value of donations decreased, which could be a consequence of the economic crisis (see Table 1).

Table 1. The value of donations in the "Leaders of Philanthropy" contest in the period 2007-2013

\begin{tabular}{|c|c|c|c|}
\hline Year & $\begin{array}{c}\text { The number of } \\
\text { companies in the } \\
\text { ranking }\end{array}$ & $\begin{array}{c}\text { The total value of } \\
\text { donations }\end{array}$ & $\begin{array}{c}\text { Average } \\
\text { for } 1 \\
\text { donation }\end{array}$ \\
\hline 2007 & 24 & 50348076 & 2097837 \\
\hline 2008 & 28 & 76415926 & 2729140 \\
\hline 2009 & 22 & 73961625 & 3361892 \\
\hline 2010 & 25 & 49131709 & 1965268 \\
\hline 2011 & 31 & 81771133 & 2637778 \\
\hline 2012 & 25 & 82899417 & 3315977 \\
\hline 2013 & 22 & 130825731 & 5946624 \\
\hline
\end{tabular}

Source: Pękocka M. (2013), Coordinator of the "Leaders of Philantropy” contest, www.forumdarczyncow.pl.

The presented data shows that the number of donors varies. It was the highest in 2011 ( 31 companies) and the lowest in the years 2009 and 2013 (22 firms each year). As regards the value of donations, both the total value and the average for 1 donation has been increasing steadily. An exception was the year 2010, in which the total amount of donations was the lowest, what influenced the average value per donor. Can this be justified by the impact of the crisis on the decreasing interest of firms in philanthropy?

The majority of contest participants are large firms that operate internationally. There are also Polish firms among them, which operate in foreign 
markets. Local firms represent only a small percentage of all contest participants. The firms which provided the most funds for social purposes in 2013 are presented in Table 2 .

Table 2. The firms which provided the most funds for social purposes in 2013

\begin{tabular}{|c|c|c|c|c|}
\hline No. & Firm & Sector & $\begin{array}{c}\text { The } \\
\text { value of } \\
\text { donations }\end{array}$ & $\begin{array}{l}\text { Percentage } \\
\text { of total } \\
\text { amount } \\
100,00\end{array}$ \\
\hline 1. & PZU & $\begin{array}{l}\text { Banking, finance and } \\
\text { insurance }\end{array}$ & 65841924 & 51,3 \\
\hline 2. & $\begin{array}{l}\text { KGHM Polska } \\
\text { Miedź }\end{array}$ & $\begin{array}{l}\text { Fuel, energy, mining, } \\
\text { chemical and } \\
\text { industrial production }\end{array}$ & 22000000 & 17,8 \\
\hline 3. & PKO Bank Polski & $\begin{array}{c}\text { Banking, finance and } \\
\text { insurance }\end{array}$ & 12473512 & 9,5 \\
\hline 4. & $\begin{array}{l}\text { Polski Koncern } \\
\text { Naftowy Orlen }\end{array}$ & $\begin{array}{l}\text { Fuel, energy, mining, } \\
\text { chemical production }\end{array}$ & 7920108 & 6,0 \\
\hline 5. & $\begin{array}{l}\text { PGE Polska Grupa } \\
\text { Energetyczna }\end{array}$ & $\begin{array}{l}\text { Fuel, energy, mining, } \\
\text { chemical production } \\
\text { and construction }\end{array}$ & 5042883 & 3,7 \\
\hline 6. & $\begin{array}{l}\text { Procter \& Gamble } \\
\text { DS Polska }\end{array}$ & Good consumption & 4452065 & 3,5 \\
\hline 7. & Bank BGŻ & $\begin{array}{l}\text { Banking, finance and } \\
\text { insurance }\end{array}$ & 3200000 & 2,4 \\
\hline 8. & Atlas Group & $\begin{array}{l}\text { Fuel, energy, mining, } \\
\text { chemical production }\end{array}$ & 1940750 & 1,5 \\
\hline 9. & Pelion & Pharmacy & 1732604 & 1,3 \\
\hline 10. & $\begin{array}{l}\text { Bank Ochrony } \\
\text { Środowiska }\end{array}$ & $\begin{array}{c}\text { Banking, finance and } \\
\text { insurance }\end{array}$ & 1370000 & 1,0 \\
\hline \multicolumn{3}{|c|}{ Total } & $\begin{array}{c}130825 \\
731\end{array}$ & 100,0 \\
\hline
\end{tabular}

Source: Pękocka M. (2013), Coordinator of the "Leaders of Philantropy” contest, www.forumdarczyncow.pl. 
The data presented in Table 2 shows that the dominant groups of donors are firms belonging to fuel and energy, and banking and finance sectors. Nominally, the largest donor in 2013 was PZU, which donations accounted for more than half of the total funds provided by the 10 most generous firms. The scale of charity looks slightly different when we analyze the percentage of donations in the pre-tax profit (see Table 3).

Table 3. Firms which provided the largest percentage of their pre-tax profit for social purposes in 2013

\begin{tabular}{|c|c|c|c|c|}
\hline No. & Firm & Sector & $\begin{array}{c}\text { The } \\
\text { value of } \\
\text { donations }\end{array}$ & $\begin{array}{l}\text { Percentage of } \\
\text { donations in firm's } \\
\text { pre-tax profit (\%) }\end{array}$ \\
\hline 1. & Atlas Group & $\begin{array}{l}\text { Fuel, energy, } \\
\text { mining, chemical } \\
\text { production }\end{array}$ & 1940750 & 5,91 \\
\hline 2. & $\begin{array}{l}\text { Bałtycki Bank } \\
\text { Spółdzielczy }\end{array}$ & $\begin{array}{l}\text { Banking, finance } \\
\text { and insurance }\end{array}$ & 124800 & 5,86 \\
\hline 3. & VOTUM & Services, trade & 163892 & 2,56 \\
\hline 4. & Pelion & Pharmacy & 1732604 & 2,26 \\
\hline 5. & $\begin{array}{c}\text { Bank Ochrony } \\
\text { Środowiska }\end{array}$ & $\begin{array}{l}\text { Banking, finance } \\
\text { and insurance }\end{array}$ & 1370000 & 2,23 \\
\hline 6. & Konimpex & Services, trade & 364940 & 1,94 \\
\hline 7. & $\begin{array}{l}\text { Vive Textile } \\
\text { Recycling }\end{array}$ & Services, trade & 483494 & 1,91 \\
\hline 8. & Bank BGŻ & $\begin{array}{l}\text { Banking, finance } \\
\text { and insurance }\end{array}$ & 3200000 & 1,79 \\
\hline 9. & PZU & $\begin{array}{l}\text { Banking, finance } \\
\text { and insurance }\end{array}$ & 65841924 & 1,63 \\
\hline 10 & $\begin{array}{c}\text { Górażdże } \\
\text { Cement Group }\end{array}$ & $\begin{array}{l}\text { Fuel, energy, } \\
\text { mining, chemical } \\
\text { production and } \\
\text { construction }\end{array}$ & 1339755 & 0.67 \\
\hline
\end{tabular}

Source: Pękocka M. (2013), Coordinator of the "Leaders of Philantropy" contest, www.forumdarczyncow.pl. 
This percentage shows that the most generous firms (having donated the highest amount of money) spend only a small percentage of their income for social purposes. An example is PZU, which allocated for social purposes the largest amount of funds (nearly 60 million zl), which accounted for only $1.63 \%$ of its income. This resulted in the 1 st position in the first ranking and only 9 th position in the second one.

There are also opposite situations - the firms that have donated so modest sums that they were ranked at a distant place, allocated for social purposes a large percentage of their income (see Baltic Cooperative Bank). Which ranking is more objective, then? It probably depends on the purpose the ranking serves. If we take into account the value of funds allocated for social purposes then the first criterion will be more important. However, if we want to assess the degree of engagement and the generosity of donors - the second criterion will be more reliable.

\section{Social engagement of selected firms}

As examples of good practices in social engagement two firms were adopted for the analysis, that did not always take part in the "Leader of Philanthropy" contest or were ranked at more distant places.

Their characteristic feature is that they are located in Lodz or have their branches here and represent different types of activities. These include:

- The insurance company AVICA

- Consulting firm Infosys BPO

- Pharmaceutical firm Pelion Health Group,

- Telecommunications company Orange,

- Bank - mBank, till 2012 - BRE Bank SA.

The types of social activities of the above firms vary.

Four of them have set up their own foundations (AVIVA, Pelion Group, Orange and mBank). This made the activities of these firms more visible because the name of the foundation is typically derived from the name of the founding firm.

Social activities of presented firms can be considered from different points of view. From the point of view of the type of beneficiaries, this activity can be addressed to:

- employees,

- local community,

- children,

- the sick, the disabled and the poor,

- animals. 
From the point of view of the type of business, it can be:

- health,

- education,

- culture,

- sports,

- environmental protection.

The AVIVA insurance company takes actions both to the benefit of its employees as well as externally. The employees of the company have the ability to implement their pro-social projects that are funded by the company. This combines social activities with the improvement of relations between employees. As a part of such understood volunteering actions are taken to the benefit of children and animals.

The company carries out its social activities through its own foundation. The main areas of social activity of the company are education and health. Actions are directed primarily to children and youth. One of the actions is the organization and financing of the "Street to School" program, which aim is to equalize educational opportunities of young people. Subsequent programs are relating to health. These include (i.a.):

- Support program for the patients of the Child Health Center (Centrum Zdrowia Dziecka);

- The „Share Your Health” project in collaboration with the Against Leukemia Foundation.

The company also cooperates with the Stefan Batory Foundation implementing cultural and educational programs.

Noteworthy is the fact that the AVIVA Foundation organizes and finances support program for Polish participants in Paralympics, by funding scholarships, organizing social campaigns and supporting their image in the media [www.odpowiedzialny biznes.pl, www.pozytek.gov.pl]. Infosys BPO has not set up its own foundation but actively supports a number of foundations and associations in our city (Lodz). Social activity of the firm focuses mainly on education, culture, sport and the labor market. The firm especially takes care of animals in the Zoo in Lodz.

As a part of the firm's education supporting activities Infosys provides financial support for selected kindergartens, schools and orphanages. An example of culture supporting actions is organization of annual Infosys Ballylodz festivals that popularize the culture of India in the Lodz community. Involvement in sports activities reflects, i.a. in organizing volleyball (Infosys Volleyball Cup), rugby (Rugby Raban) tournaments and bicycle rallies. 
Worth emphasizing is the firm's support for the labor market by engaging in the Youth in Łódź program [www.odpowiedzialny biznes.pl, www.pozytek. gov.pl]. The pharmaceutical Foundation Pelion Healthcare Group took a high place in the "Leader of Philanthropy 2013" contest. Its activities are mainly related to the company's profile, i.e. health.

The firm operates through its own foundation called "I care for health" (Dbam o zdrowie). This activity is directed both to the firm's employees and to the external beneficiaries.

Employees have the chance to integrate through visiting the sights of Lodz within the "Let Lodz surprise you" (Niech Łódź Cię zaskoczy) campaign. They also have the opportunity to support their foundation by giving the tip of their salaries for its purposes.

Employee volunteering is realized through participation in the organization of the World Day of Dignity (Dignity Day), when youth meetings in schools with well-known personalities are organized.

External activities of the Foundation "I care for health" cover many initiatives. The most important are:

- the implementation of the medicines financing program for people in difficult financial circumstances,

- the organization of the marathon: I care for Health - Lodz Marathon,

- launch of the „Eco-project” program, which aims to raise awareness of the local community of the negative effects of pollution. The employees established „Eco Team” that initiates various pro-environmental actions.

Noteworthy is the firm's patronage over old pharmacies and pharmacy museums across the country [Polscy liderzy korporacyjnej filantropii, http://www. forbes.pl]. Telecommunications company Orange operates mainly through its own foundation under the same name. The main area of interest of the company is supporting children and young people in need of assistance in the field of education and health.

The most important activities in this area include:

- helping children and young people access modern education,

- domestic violence prevention program, which is implemented during sessions and workshops involving young people and educators,

- financial support and cooperation with the largest social organizations in Poland (Academy for the Development of Philanthropy, Synapsis Foundation, Friends of Integration Association) in order to help children and young people,

- rehabilitation program for young children with hearing loss, 
- financial support for other foundations and associations helping sick children, such as the Foundation for Children with cancer (Fundacja na Rzecz Dzieci z choroba nowotworowa), Association for Children with Disabilities (Stowarzyszenie Pomocy Dzieciom Niepetnosprawnym),

- financial support for people in need,

- support for customers in a difficult situation (disasters, natural disasters, etc.),

- participation in annual activities of the Great Orchestra of Christmas Charity Foundation,

- $\quad$ support for cultural institutions such as Grand Theatre of the National Opera [www.odpowiedzialnybiznes.pl, www.pozytek.gov.pl, www.orange.pl, www.orange-cs.pl].

Social activity of the mBank (till 2012 - BRE Bank SA) is addressed to both the employees and external beneficiaries. The offer for $\mathrm{mBank}$ employees is very broad and includes (i.a.):

- courses and training organized in order to upgrade their skills,

- providing medical care in private health care,

- additional life insurance,

the organization of the event: „Let's do something Good Together,” which is a kind of employee volunteering funded by the Foundation,

The „Christmas full of dreams” program. This is an annual Christmas campaign for people in the charge of public benefit organizations.

mBank acts externally through its own foundation. It cooperates with other foundations and associations throughout Poland. The activities of the Foundation focus on the problems of education, health and culture.

The main activities in the field of education include:

- funding awards for laureates of economy knowledge contests,

- bridge scholarship programs for students from rural areas and small towns,

- material aid for schools,

- sponsorship of research and publications.

In the field of health and social care the following activities are taken (i.a.): cooperation with the Polish Humanitarian Organization (Polska Akcja Humanitarna),

- participation in the „Pajacyk” project, which aim is to level educational opportunities of children from poor families,

- cooperation with the Synapsis Foundation in the implementation of the „Autism Academy for NGO's. Roads to social and professional activation of people with autism”. 
In the field of culture the Foundation supports cultural events, publications, authors and organizers of cultural activities. In addition, it cooperates with the Royal Castle in Warsaw and the Amber Museum in Gdańsk [Polscy liderzy korporacyjnej filantropii 2014].

\section{Conclusions}

The conducted research proves that social engagement of Polish firms is at the early stage of development. The annual increase in the number of firms involved in this type of activity may be the confirmation of the fact that companies see the need of engagement in solving social problems and the impact of such activities on the development of their business.

Characteristically, socially engage mainly large companies, often with foreign capital. This is probably due to the fact that they are recognizable firms that treat CSR as an element of competition. In turn, companies with foreign capital are often obliged to undertake this type of activity.

Small share of SMEs in social activities results, on the one hand, from the lack of knowledge and experience in this field and, on the other hand, from the limited amount of financial resources at their disposal. The presented examples of prosocial Polish firms do not allow to draw conclusions, but they allow to present some observations.

The presented firms can be divided into two groups:

- those that have a program of social activities and consistently implement it (AVIVA, mBank, Orange);

- those that operate spontaneously and occasionally.

In the first group, the activity is directed both to the employees and to the external beneficiaries. In the latter case, actions are also taken in collaboration with non-governmental organizations and even with the local community. Four of the analyzed firms have set up their own foundations, which activities have a wide range and apply to health, education, culture and sport (except Pelion Groups). The environmental and social exclusion issues are taken rarely.

Children and young people are the main beneficiaries. Support for these groups is postulated by all the analyzed firms. When it comes to the generic range of activities, most companies take the whole range of activities in education, health and social care, culture and sports. The exception is Pelion Group, which undertakes social activities related to the profile of its business - that is supporting and organizing actions in the area of health and social care. 
The question arises: what are the reasons for low interest of firms in social issues?

The main barriers are:

- lack of understanding of the concept of Corporate Social Responsibility among the majority of firms,

- lack of awareness of the benefits resulting from social engagement,

- lack of capital, especially in case of SMEs,

- mistrust of the beneficiaries,

- lack of professionals showing ways of implementation of the CSR and the benefits of such activities.

\section{References}

Gainer B. (2011), Corporate Social Responsibility [in:] Third Sector Research, Rupert Taylor editor, New York.

Kuraszko J. (2008), Wspótpraca biznesu z organizacjami pozarządowymi w kontekście spotecznej odpowiedzialności firm (CSR) „Trzeci Sektor”, nr 12, Warszawa.

Łukasiewicz-Kamińska A. (2011), Spoteczna odpowiedzialność przedsiębiorstwa flnansowego, Difin, Warszawa.

Pękocka M. (2013), Koordynator konkursu „Liderzy Filantropii” 2013, www.forumdarczyncow.pl, access 10.10.2014.

Polscy liderzy korporacyjnej filantropii, http://www.forbes.pl, access 12.10.2014.

Promoting a European Framework for Corporate Social Responsibility, Green Paper, European Commission.

Roguska B. (2004), Wtaściciel, pracodawca, obywatel - rekonstrukcja wizerunku prywatnego przedsiębiorcy [in:] L. Kolarska-Bobińska (ed.), Świadomość ekonomiczna spoteczeństwa i wizerunku biznesu, Instytut Spraw Publicznych, Warszawa.

Rok B., Stolorz S., Stanny D. (2009), Menedżerowie 500 i odpowiedzialny biznes. Wiedza - postawy - praktyka, Forum Obywatelskiego Biznesu, Warszawa.

Rudzki Inkubator Przedsiębiorczości Sp. z.o.o (2007), Spoteczna odpowiedzialność biznesu - CSR w matym i średnim przedsiębiorstwie - obecna pozycja i przyszte trendy. Badanie porównawcze przeprowadzone w Niemczech, Francji i w Polsce, Ruda Śląska.

Stafiej-Bartosik A., Łukasiak P. (2008), Metoda K4 czyli spoteczna odpowiedzialność biznesu w Polsce-podejście praktyczne z perspektywy czterech kapitatów, „Trzeci Sektor", nr 12.

www.forumdarczyncow.pl, access 1.10.2014.

www.odpowiedzialnybiznes.pl, access 1.10.2014. 
www.orange.pl, access 1.10.2014.

www.orange-csr.pl, access 1.10.2014.

www.pozytek.gov.pl, access 1.10.2014. 